\title{
Growth, Physiological and Biochemical Responses of Two Greek Cotton Cultivars to Salt Stress and their Impact as Selection Indices for Salt Tolerance
}

\author{
Maria-Anna MOUSSOURAKI ${ }^{1 \mathrm{a}}$, Eleni TANI ${ }^{\mathrm{lb}}$, Anna VELLIOU ${ }^{1}$, \\ Maria GOUFA ${ }^{1}$, Maria PSYCHOGIOU ${ }^{2}$, Ioannis E. PAPADAKIS ${ }^{3}$, \\ Eleni M. ABRAHAM ${ }^{4 *}$ \\ ${ }^{1}$ Agricultural University of Athens, Department of Crop Science, Laboratory of Plant Breeding and Biometry, Iera Odos 75, 11855 \\ Athens,Greece;_granny@yahoo.com;marog@aua.gr;marianna.mous7@gmail.com;annavelliou2@gmail.com \\ ${ }^{2}$ Agricultural University of Athens, Department of Natural Resources Management and Agricultural Engineering, Laboratory of Agricultural \\ Hydraulics, Iera Odos 75, 11855 Athens, Greece; mariapsy1@gmail.com \\ ${ }^{3}$ Agricultural University of Athens, Laboratory of Pomology, Department of Crop Science, Iera odos 75,11855, Athens, Greece; \\ papadakis@aua.gr \\ ${ }^{4}$ Aristotle University of Thessaloniki, School of Agriculture, Forestry and Natural Environment, Laboratory of Range Science, 54124 \\ Thessaloniki, Greece; eabraham@for.auth.gr (*corresponding author) \\ $\mathrm{a}, \mathrm{b}$ These authors contributed equally to this work
}

\begin{abstract}
Soil salinity is a major constrain of crop productivity. Upland cotton (Gossypium hirsutum L.) is an important fiber crop worldwide and a major agricultural product in Greece. Two commercial cotton cultivars ('Hersi' and 'ST 318') were studied to compare their response under non-saline and saline conditions in a greenhouse experiment. Salt stress on plants was imposed by two different approaches: a gradual and an initial acclimatization to a non-lethal $\mathrm{NaCl}$ concentration $(150 \mathrm{mM})$. To explore salt stress responses, growth (height of plants, roots, shoots and leaves dry weight, reproductive shoots, Salinity Sensitivity Index), gas exchange (Photosynthetic rate, Stomatal conductance, Transpiration rate and Water Use Efficiency) and biochemical parameters (proline, $\mathrm{H}_{2} \mathrm{O}_{2}$ and MDA content), were examined as well as ion homeostasis. 'Hersi' had significantly higher dry weight of roots, shoots and leaves, lower salinity sensitivity index of roots compared to 'ST 318 '. In this regard, it appears that 'Hersi' cultivar performed better than 'ST 318' to increased salinity conditions, due to better control of gas exchange parameters and $\mathrm{K}^{+} / \mathrm{Na}^{+}$homeostasis as well as better membrane integrity. Furthermore, the gradual acclimatization to the $150 \mathrm{mM} \mathrm{NaCl}$ concentration had a milder effect on both cultivars compared to the initial acclimatization.
\end{abstract}

Keywords: Gossypium hirsutum; gas exchanges parameters; ion analyses; lipid peroxidation; salinity tolerance

\section{Introduction}

Soil salinity negatively affects $20 \%$ of the world's cultivated lands and more than half of all irrigated lands (FAO 2015). The problem is expanding due to intense agricultural practices and irrigation. High salt concentrations in the soil affect the yield of agricultural crops in various ways including delaying in plant growth and development, disturbance of enzymatic activities and malfunctions in photosynthetic activity (Parihar et al., 2015). In order to enhance productivity and utilize marginal areas, it is of great importance to improve salt tolerance of crop plants.
Soil salinity affects plant growth through two stages: the first stage is the osmotic stress which is then followed by ionic stress (Munns and Tester, 2008; Carillo et al., 2011). During the first phase, water absorption of root decreases dramatically with a concomitant water loss from leaves due to osmotic stress of high salt concentration in soil and plants (Munns and Gilliham, 2015). Osmotic stress causes a sudden removal of water, resulting in a leaky plasma membrane. Thus, abnormal amounts of salt are allowed to enter within the root cell and move along the stem (Munns, 2002; Munns and Tester, 2008). The resulting low water potential prevents the process of photosynthesis and transpiration due to the reduction in stomatal conductance induced by stomatal closure (Brugnoli and Lauteri, 1991; Rahnama et al., 2010; Ozyigit et al., 2017). On the other 
hand, as far as ionic stress is concerned, elevated ion concentrations of $\mathrm{Na}^{+}$and $\mathrm{Cl}^{-}$in the soil solution are antagonistic to other inorganic nutrients, resulting in an imbalance of cellular ionic homeostasis and toxic side effects at a metabolic level. $\mathrm{Na}^{+}$antagonizes $\mathrm{K}^{+}$, which plays an important role in regulating the osmotic potential of plant cells and activates many enzymes involved in respiration and photosynthesis (Hasegawa et al., 2000).

Plants can survive under saline conditions and evolve to better tolerate saline conditions through alternations in morphological, physiological and metabolic level (Munns and Tester, 2008; Parihar et al., 2015). These special alterations include ion homeostasis, photosynthesis adjustment, antioxidant enzyme induction, osmotic adjustments, and combinations of these factors (Parida and Das, 2005; Ashraf and Foolad, 2007; Peng et al., 2016; Wang et al., 2016; Rahneshan et al., 2018). Furthermore, a crucial parameter for salinity tolerance is to maintain an optimal cytoplasmic $\mathrm{K}^{+} / \mathrm{Na}^{+}$ratio. The $\mathrm{K}^{+} / \mathrm{Na}^{+}$ratio has been used in many studies as a successful salinity resistance index for selecting resistant cotton varieties. Moreover the concentration of $\mathrm{Ca}+$ and $\mathrm{Mg}+$ in response to high salinity plays a critical role in osmoregulation and homeostasis of plant cells (Hadi and Karimi, 2012; Thu et al., 2017)

Upland cotton (Gossypium hirsutum L.) is one of the world's primary fiber crop which is widely cultivated throughout the world (Constable et al., 2015). Furthermore, is a major agricultural product in Greece, which is the biggest cotton producer in EU (Cotton Incorporated, 2017/18). In addition to fiber production, cottonseeds are an important source of oil for human consumption. Thirdly, cotton pie (a byproduct derived from the oil production process) is used in animal husbandry, making it an excellent feed for ruminants, due to its high protein level (Dogan et al., 2012). Moreover, cottonseed flour could be a great source of protein for the nutrition of the ever-growing population of the planet. It is, therefore, a considerable source of income for Greek farmers and an important factor in the development of agriculture (Papakosta-Tasopoulou, 2013). Cotton is one of the most salt tolerant crops (Ashraf and Wu, 1994; Ashraf, 2002; Basal, 2010). However, considerable variation exists between varieties and in several cases salinity stress causes a series of negative effects on cotton growth, yield, and fiber quality (Razzouk and Whittington, 1991; Ashraf, 2002; Zhang et al., 2014). Identification of salt-tolerance in cotton germplasm is an important goal for further improvement in cotton production. Previous studies conducted on this issue revealed great genotypic variability for salinity tolerance in cotton (Akhtar et al., 2010; Zhang et al., 2014; Ozyigit et al., 2017; Wang et al., 2017ab;). Therefore, the present research was conducted in order to: a) determine salinityinduced changes in growth, gas exchange parameters, mineral concentrations, osmotic adjustment and $\mathrm{H}_{2} \mathrm{O}_{2}$ accumulation in two commercially cultivated Greek cotton cultivars and b) identify the parameters that are most crucial for rendering cultivars tolerant to salinity at early growth stages in upland cotton. Moreover, in the experimental procedure the plants are usually stressed by initial acclimatization of high concertation of $\mathrm{NaCl}$. However, this is not the case in nature, where the $\mathrm{NaCl}$ concentration rises gradually. Thus in the present study plant responses were tested under both initial and gradual application of $\mathrm{NaCl}$.

As it has been pointed out, cotton is the most important fiber culture and one of the most profitable crops in the world. Therefore, the information that was gathered from this study and the presenting results may provide useful criteria in further research into the understanding and improvement of the complex mechanisms of cotton plant resistance in order to utilize it in marginal environments.

\section{Materials and Methods}

\section{Biological material and growth conditions}

Two Upland cotton cultivars, 'Hersi' and 'ST 318', supplied by Greenco and Pioneer-Greece respectively, which are early maturing cultivars with adaptability to multiple environments, were evaluated for their salt tolerance. Three seeds of each cultivar were planted into every pot, of $24 \mathrm{~cm}$ diameter filled with Gramoflor's Gartner Substrate. After plant emergence, the most vigorous seedling remained in every pot. We used five pots per each treatment (number of total plants 40 ). The pots were placed in greenhouse the 1rst week of May and were exposed to normal sunlight and photoperiod. The $\mathrm{NaCl}$ treatments initiated 11 days after seedling emergence as follows: a) control, no salt; b) initial acclimatization of 50 $\mathrm{mM} \mathrm{NaCl} ; \mathrm{c}$ ) initial acclimatization of $150 \mathrm{mM} \mathrm{NaCl}$ and d) gradual acclimatization to $50-100-150 \mathrm{mM}$ final $\mathrm{NaCl}$ concentrations. The experiment was arranged in a completely randomize block with five replications. The salt concentration in the gradual acclimatization was increased from 0 to 50,100, and $150 \mathrm{mM} \mathrm{NaCl}$ every 10 days. Plants were watered every 3 days after the initiation of treatments. The experiment lasted 43 days. Then, at the stage of eight leaves, the above- and underground parts of plants were harvested. After harvesting soil was removed from the roots and plant parts (roots, shoots and leaves) were dried at 65 ${ }^{\circ} \mathrm{C}$ for 48 hours. Furthermore, leaves, roots and shoots of each plant were sampled, immediately frozen in liquid nitrogen and stored at $-80^{\circ} \mathrm{C}$ for the biochemical analyses.

\section{Measurements of growth and gas exchange parameters}

The net weight of roots, shoots and leaves, the aboveground plant length and the number of reproductive shoots were measured on the harvesting day. Moreover, the dry weight of roots, shoots and leaves was determined the day after harvesting. The salinity sensitivity index (IS) based on dry weight of roots, shoots and leaves was estimated according to (Hamrouni et al., 2008) as IS $=\left(\mathrm{Ws}_{\mathrm{W}}-\mathrm{Wc}\right.$ ) $/ \mathrm{Wc}$ $\times 100$, in which Ws and Wc were the values of weight of the salt-stressed and control plants, respectively.

The net photosynthesis (A), stomatal conductance (gs), transpiration rate $(\mathrm{E})$, internal $\mathrm{CO}_{2}$ concentration $(\mathrm{Ci})$ were measured by using a portable photosynthetic system (LICOR-6400, Lincoln, NE, USA). The measurements were made on the uppermost fully expanded leaf, between 12:00 and 14:00 h, under a controlled atmosphere (atmospheric $\mathrm{CO}_{2} 380 \mu \mathrm{mol} \cdot \mathrm{mol}^{-1}$ and air flow rate 500 $\left.\mu \mathrm{mol} \cdot \mathrm{s}^{-1}\right)$. Photosynthetically active radiation (PAR) was set at $1700 \mu \mathrm{mol} \mathrm{m} \mathrm{s}^{-1}$ by a red/blue external light source. The instantaneous water use efficiency (WUE) was calculated from the ratio between $\mathrm{CO}_{2}$ assimilation and leaf transpiration $(\mathrm{A} / \mathrm{E})$. 
708

\section{Determination of ion concentrations}

Nutrient analyses were carried out on dried plant tissues. Samples were ground into a mill and after dry ashing in a muffle furnace at $500{ }^{\circ} \mathrm{C}$ for 8 hours and dissolution of ash with dilute aqua regia, the content of $\mathrm{K}, \mathrm{Na}, \mathrm{Ca}$ and $\mathrm{Mg}$ were determined (Jones, 2001). The concentration of potassium $(\mathrm{K})$ and sodium $(\mathrm{Na})$ was carried out using a flame photometer (Corning 410, Sherwood Scientific Ltd) and the determination of calcium $(\mathrm{Ca})$ and magnesium $(\mathrm{Mg})$ using a flame atomic absorption spectrophotometer (Varian AA-20). For the determination of $\mathrm{Cl}$ content, plant samples were extracted in distilled water by shaking for $3 \mathrm{~h}$. The $\mathrm{Cl}$ content in the extracts was analyzed by potentiometric titration using an automatic titrator (Titrino 702 Methohm).

Determination of proline, hydrogen peroxide $\left(\mathrm{H}_{2} \mathrm{O}_{2}\right)$ and malondialdehyde (MDA)

Proline accumulation in leaves was determined spectrophotometrically (Perkin-Elmer LAMBDA ${ }^{\text {ma }} \quad 1 \mathrm{~A}$ UV/Vis Spectophotometer) according to the ninhydrin method described by (Bates et al., 1973). The method was implemented with some modifications.

Hydrogen peroxide $\left(\mathrm{H}_{2} \mathrm{O}_{2}\right)$ and malondialdehyde (MDA) (Leidi and Saiz, 1997) leaf contents were measured spectrophotometrically according to the methods described by (Heath and Packer, 1968) and (Alexieva et al., 2001), which were implemented with some modifications.

\section{Statistical analysis}

The effect of treatments and cultivars on growth, gas exchange and biochemical parameters was detected by a two-way ANOVA using the Statgraphics Centurion XVI statistical analysis package. The means were compared by Tukey test at 0.05 probability level. The biochemical parameters (proline, $\mathrm{H}_{2} \mathrm{O}_{2}, \mathrm{MDA}$ ) were estimated as the ratio of the biochemical parameters of plants under salt stress in relation to the values of the controls.

\section{Results}

\section{Plant growth and gas exchangeparameters}

The salt treatments significantly $(\mathrm{P}<0.05)$ affected the growth parameters (height, dry weight, number of reproductive shoots), salinity sensitivity index and gas exchange parameters (A, gs, Ci, E, WUE) (Table 1, 2, 3). On the other hand, the cultivars had a significant effect only on dry weight, salinity sensitivity index, $\mathrm{A}$, gs and $\mathrm{Ci}$ (Tables $1,2,3)$. In addition, the interaction between salt treatments and cultivars was not statistically significant for any of the growth and gas exchange parameters (Tables 1, 2, 3) indicating that the salt treatments effect on the cultivars was consistent.

The growth parameters were not significantly affected by $50 \mathrm{mM}$ treatment with only exception the height and shoot dry weight, which were significantly reduced, compared to control (Table 1). The lowest values for all the growth parameters were recorded under initial acclimatization of $150 \mathrm{mM} \mathrm{NaCl}$ (Table 1). However, the root dry weight and the number of reproductive shoots at gradual acclimatization and initial acclimatization of 150
$\mathrm{mM} \mathrm{NaCl}$ did not significantly differ (Table 1). The highest salinity sensitivity index (absolute number) was recorded at the initial acclimatization of $150 \mathrm{mM} \mathrm{NaCl}$, while the salinity sensitivity index at $50 \mathrm{mM} \mathrm{NaCl}$ and gradual acclimatization for shoot and leaf dry weight did not significantly differ (Table 2).

Gas-exchange parameters of gs and $\mathrm{Ci}$ were the only that was significantly reduced at $50 \mathrm{mM} \mathrm{NaCl}$ treatment compared to the control (Table 3). Moreover, the gradual acclimatization and initial acclimatization of $150 \mathrm{mM} \mathrm{NaCl}$ had significantly lower gas-exchange parameters compared to the control and $50 \mathrm{mM} \mathrm{NaCl}$ treatment, while no significant differences were detected between them (Table 3).

'Hersi' had significantly higher dry weight of roots, shoots and leaves (Table 1) and lower salinity sensitivity index of roots (Table 2) compared to 'ST 318', while the cultivars did not significantly differ in height, number of reproductive shoots and salinity sensitivity index of shoots and leaves. The gas exchange parameters of $\mathrm{A}$, gs and $\mathrm{Ci}$ were significantly higher in 'Hersi' than in 'ST 318' but E and WUE were similar (Table 3).

\section{Ionic homeostasis}

$\mathrm{NaCl}$ treatments affected significantly all studied parameters of plant's ionic homeostasis (leaves' and roots' ion content in $\mathrm{K}^{+}, \mathrm{Na}^{+}$and $\mathrm{Cl}^{-}, \mathrm{K}^{+} / \mathrm{Na}^{+}$ratio) (Table 4 and 5). Contents of $\mathrm{Na}$ and $\mathrm{Cl}$ were increased in the presence of $\mathrm{NaCl}$ in both leaves and roots while the concentration of $\mathrm{K}^{+}$ was reduced in leaves (Table 4) but increased in roots (Table 5). For micronutrient $\mathrm{Mg}^{2+}$, an increase was observed comparing with the controls and no reduction of accumulation of $\mathrm{Ca}^{2+}$ was found in both cultivars (Fig. 1). The $\mathrm{Mg}^{2+}$ and $\mathrm{Ca}^{2+}$ was not affected for both cultivars in the roots (data not shown).

In contrast, leaves $\mathrm{Na}^{+}$content and $\mathrm{K}^{+} / \mathrm{Na}^{+}$ratio were cultivar-dependent. Moreover, significant interactions in $\mathrm{Na}^{+}, \mathrm{K}^{+}$content and $\mathrm{K}^{+} / \mathrm{Na}^{+}$ratio were observed. That means that the two cultivars behaved differently under stressed conditions for $\mathrm{Na}^{+}$and $\mathrm{K}^{+}$accumulation. In particular, 'Hersi' tended to accumulate less $\mathrm{Na}^{+}$in leaves, with no reduction of $\mathrm{K}^{+}$content, maintaining higher values of $\mathrm{K}^{+} / \mathrm{Na}^{+}$ratio compared to 'ST 318' under salt stress (Fig. 1). Leaves' $\mathrm{Cl}^{-}$content in salt stressed plants was much higher than $\mathrm{Na}^{+}$content, in both cultivars, indicating that they can restrict the influx of $\mathrm{Na}^{+}$ions, comparing to $\mathrm{Cl}$ ions. This mechanism seems to be more efficient for 'Hersi' cultivar than for 'ST 318'. Under gradual acclimatization both cultivars showed better ion homeostasis compared to initial acclimatization i.e. higher $\mathrm{K}^{+}$, lower $\mathrm{Na}^{+}$and $\mathrm{Cl}^{-}$and a higher value of the $\mathrm{K}^{+} / \mathrm{Na}^{+}$ratio.

\section{Biochemical parameters}

The ratio of proline content was gradually increased, while the corresponding ratio of $\mathrm{H}_{2} \mathrm{O}_{2}$ and MDA content was decreased by increasing the salt concentration from 50 $\mathrm{mM} \mathrm{NaCl}$ to 150 (both by gradual and initial acclimatization) (Table 6) in relation to the control. Regarding the tested cultivars, 'Hersi' obtained higher ratio of proline content compared to 'ST 318 ' at $50 \mathrm{mM} \mathrm{NaCl}$ and at gradual acclimatization (50-100-150 mM), whereas lower at the initial acclimatization of $150 \mathrm{mM} \mathrm{NaCl}$ (Fig. 
2). Additionally, 'Hersi' had lower ratio of $\mathrm{H}_{2} \mathrm{O}_{2}$ content 'Hersi' kept lower ratio of MDA content in comparison to than 'ST 318' at gradual and initial acclimatization of 150 'ST 318 ' at $50 \mathrm{mM} \mathrm{NaCl}$, while higher at $150 \mathrm{mM} \mathrm{NaCl}$ $\mathrm{mM} \mathrm{NaCl}$, but higher at $50 \mathrm{mM} \mathrm{NaCl}$ (Fig. 2). Finally, initial acclimatization (Fig. 2).

Table 1. The effect of salt treatment and cultivar on plants' growth parameters (mean $\pm \mathrm{SE}$ )

\begin{tabular}{|c|c|c|c|c|c|}
\hline \multirow{2}{*}{$\begin{array}{l}\text { Salt Treatment } \\
\quad(\mathrm{mMNaCl})\end{array}$} & \multirow{2}{*}{$\begin{array}{l}\text { Height } \\
(\mathrm{cm})\end{array}$} & \multicolumn{3}{|c|}{ Dry Weight (g) } & \multirow{2}{*}{ Reproductive Shoots } \\
\hline & & Root & Shoot & Leaf & \\
\hline Control & $69 \pm 1.9 a$ & $2.93 \pm 0.2 \mathrm{a}$ & $9.5 \pm 0.4 \mathrm{a}$ & $17 \pm 1.5 \mathrm{a}$ & $7.1 \pm 0.4 \mathrm{a}$ \\
\hline 50 & $60 \pm 2.5 b$ & $2.61 \pm 0.2 \mathrm{ab}$ & $6.9 \pm 0.7 b$ & $13 \pm 1.4 a b$ & $6.6 \pm 0.6 \mathrm{ab}$ \\
\hline $50-100-150$ & $56 \pm 1.3 b$ & $1.93 \pm 0.2 \mathrm{bc}$ & $5.5 \pm 0.2 b$ & $11 \pm 0.4 b$ & $5.3 \pm 0.2 b c$ \\
\hline 150 & $44 \pm 0.91 c$ & $1.19 \pm 0.1 \mathrm{c}$ & $3.5 \pm 0.3 c$ & $7 \pm 0.5 c$ & $4.5 \pm 0.3 c$ \\
\hline \multicolumn{6}{|l|}{ Cultivar } \\
\hline 'Hersi' & $58 \pm 2.7$ & $2.6 \pm 0.2 \mathrm{a}$ & $6.7 \pm 0.6 \mathrm{a}$ & $14 \pm 1.2 \mathrm{a}$ & $6.0 \pm 0.4$ \\
\hline 'ST 318' & $56 \pm 2.0$ & $1.68 \pm 0.2 b$ & $5.8 \pm 0.5 b$ & $11 \pm 0.9 b$ & $5.8 \pm 0.4$ \\
\hline \multicolumn{6}{|l|}{ Source of variation } \\
\hline Treatment (A) & $\mathrm{P}<0.05$ & $\mathrm{P}<0.05$ & $\mathrm{P}<0.05$ & $\mathrm{P}<0.05$ & $\mathrm{P}<0.05$ \\
\hline Cultivar (B) & $\mathrm{Ns}^{* *}$ & $\mathrm{P}<0.05$ & $\mathrm{P}<0.05$ & $\mathrm{P}<0.05$ & ns \\
\hline AXB (Interaction) & ns & ns & ns & ns & ns \\
\hline
\end{tabular}

Note: Means followed by the same letter in the column did not significantly differ (Tukey test, $\mathrm{p}>0.05$ ). ns: not significant at 0.05 level.

Table 2. The effect of salt treatment and cultivar on Salinity Sensitivity Index for dry weight (mean \pm SE)

\begin{tabular}{|c|c|c|c|}
\hline \multirow{2}{*}{$\begin{array}{l}\text { Salt Treatment } \\
\qquad(\mathrm{mM} \mathrm{NaCl})\end{array}$} & \multicolumn{3}{|c|}{ Salinity Sensitivity Index for Dry Weight } \\
\hline & Root & Shoot & Leaf \\
\hline 50 & $-11 \pm 4.4 a$ & $-27 \pm 7.1 \mathrm{a}$ & $-20 \pm 7.3 a$ \\
\hline $50-100-150$ & $-36 \pm 4.9 b$ & $-42 \pm 2.0 \mathrm{a}$ & $-30 \pm 2.6 a$ \\
\hline 150 & $-60 \pm 2.1 c$ & $-63 \pm 2.5 b$ & $-60 \pm 2.6 b$ \\
\hline \multicolumn{4}{|l|}{ Cultivar } \\
\hline 'Hersi' & $-27 \pm 6.2 \mathrm{a}$ & $-41 \pm 6.1$ & $-32 \pm 6.4$ \\
\hline 'ST 318’ & $-43 \pm 5.9 b$ & $-46 \pm 4.8$ & $-38 \pm 5.3$ \\
\hline \multicolumn{4}{|l|}{ Source of variation } \\
\hline Treatment $(\mathrm{A})$ & $\mathrm{P}<0.05$ & $\mathrm{P}<0.05$ & $\mathrm{P}<0.05$ \\
\hline Cultivar $(\mathrm{B})$ & $\mathrm{P}<0.05$ & ns & $\mathrm{ns}$ \\
\hline AXB (Interaction) & ns & $\mathrm{ns}$ & $\mathrm{ns}$ \\
\hline
\end{tabular}

Note: Means followed by the same letter in the column did not significantly differ (Tukey test, $\mathrm{p}>0.05$ ). ns: not significant at 0.05 level.

Table 3. The effect of salt treatment and cultivar on plants' gas exchange parameters (A: Photosynthetic rate; gs: stomatal conductance; Ci: Intercellular $\mathrm{CO}_{2}$ concentration; E: Transpiration rate; WUE: Water Use Efficiency) (mean $\pm \mathrm{SE}$ )

\begin{tabular}{|c|c|c|c|c|c|}
\hline $\begin{array}{l}\text { Salt Treatment } \\
\qquad(\mathrm{mM} \mathrm{NaCl})\end{array}$ & $\begin{array}{c}\mathrm{A} \\
\left(\mu \mathrm{mol} \mathrm{CO} 2 \mathrm{~m}^{-2} \mathrm{~s}^{-1}\right)\end{array}$ & $\begin{array}{c}\mathrm{gs} \\
\left(\mathrm{mol} \mathrm{H}_{2} \mathrm{O} \mathrm{m}^{-2} \mathrm{~s}^{-1}\right)\end{array}$ & $\begin{array}{c}\mathrm{Ci} \\
\left(\mu \mathrm{mol} \mathrm{CO}_{2} \mathrm{~mol} \mathrm{air}^{-1}\right)\end{array}$ & $\begin{array}{c}\mathrm{E} \\
\left(\mathrm{mmol} \mathrm{H}_{2} \mathrm{O} \mathrm{m}^{-2} \mathrm{~s}^{-1}\right)\end{array}$ & $\begin{array}{c}\text { WUE } \\
\left(\mu \mathrm{mol} \mathrm{CO} 2 \mathrm{mmol}^{-1} \mathrm{H}_{2} \mathrm{O}\right)\end{array}$ \\
\hline Control & $21.1 \pm 0.60 \mathrm{a}^{*}$ & $0.32 \pm 0.011 \mathrm{a}$ & $218 \pm 7 a$ & $10.3 \pm 0.12 \mathrm{a}$ & $2.05 \pm 0.57 \mathrm{a}$ \\
\hline 50 & $19.3 \pm 0.80 \mathrm{a}$ & $0.26 \pm 0.012 b$ & $189 \pm 6 b$ & $9.5 \pm 0.33 \mathrm{a}$ & $2.10 \pm 0.11 \mathrm{a}$ \\
\hline $50-100-150$ & $16.1 \pm 0.48 b$ & $0.15 \pm 0.008 c$ & $156 \pm 6 c$ & $6.6 \pm 0.21 b$ & $2.46 \pm 0.69 b$ \\
\hline 150 & $14.0 \pm 0.49 \mathrm{~b}$ & $0.14 \pm 0.011 \mathrm{c}$ & $134 \pm 7 \mathrm{c}$ & $6.04 \pm 0.24 b$ & $2.41 \pm 0.11 b$ \\
\hline \multicolumn{6}{|l|}{ Cultivar } \\
\hline 'Hersi' & $18.2 \pm 0.79 \mathrm{a}$ & $0.23 \pm 0.021 \mathrm{a}$ & $183 \pm 9 a$ & $8.1 \pm 0.50$ & $2.32 \pm 0.87$ \\
\hline 'ST 318’ & $16.8 \pm 0.93 b$ & $0.20 \pm 0.022 b$ & $164 \pm 10 b$ & $8.1 \pm 0.54$ & $2.18 \pm 0.69$ \\
\hline \multicolumn{6}{|l|}{ Source of variation } \\
\hline Treatment (A) & $\mathrm{P}<0.05$ & $\mathrm{P}<0.05$ & $\mathrm{P}<0.05$ & $\mathrm{P}<0.05$ & $\mathrm{P}<0.05$ \\
\hline Cultivar (B) & $\mathrm{P}<0.05$ & $\mathrm{P}<0.05$ & $\mathrm{P}<0.05$ & $\mathrm{~ns}^{* *}$ & ns \\
\hline AXB (Interaction) & ns & ns & ns & ns & ns \\
\hline
\end{tabular}


710

Table 4. The effect of salt treatment and cultivar on plants' ion contents in leaves (mean $\pm \mathrm{SE}$ )

\begin{tabular}{ccccc}
\hline $\begin{array}{c}\text { Salt Treatment } \\
(\mathrm{mM} \mathrm{NaCl})\end{array}$ & $\begin{array}{c}\mathrm{K}^{+} \text {Content } \\
\left(\mathrm{mg} \mathrm{g}^{-1}\right)\end{array}$ & $\begin{array}{c}\mathrm{Na}^{+} \text {Content } \\
\left(\mathrm{mg} \mathrm{g}^{-1}\right)\end{array}$ & $\begin{array}{c}\mathrm{K}^{+} / \mathrm{Na}^{+} \\
\text {Ratio }\end{array}$ & $\begin{array}{c}\mathrm{Cl} \text { Content } \\
\left(\mathrm{mg} \mathrm{g}^{-1}\right)\end{array}$ \\
\hline Control & $26.95 \pm 1.43 \mathrm{a}$ & $0.69 \pm 0.06 \mathrm{a}$ & $40.82 \pm 4.54 \mathrm{a}$ & $7.74 \pm 1.61 \mathrm{c}$ \\
$50-100-150$ & $25.20 \pm 1.04 \mathrm{ab}$ & $8.42 \pm 0.50 \mathrm{~b}$ & $3.04 \pm 0.24 \mathrm{~b}$ & $47.38 \pm 1.68 \mathrm{~b}$ \\
150 & $24.38 \pm 1.16 \mathrm{~b}$ & $15.41 \pm 2.42 \mathrm{c}$ & $1.80 \pm 0.34 \mathrm{~b}$ & $60.95 \pm 2.64 \mathrm{a}$ \\
Cultivar & & & & $37.77 \pm 9.96 \mathrm{a}$ \\
'Hersi' & $24.78 \pm 1.09 \mathrm{a}$ & $6.57 \pm 2.10 \mathrm{a}$ & $12.94 \pm 6.95 \mathrm{a}$ & $39.61 \pm 11.26 \mathrm{a}$ \\
'ST 318' & $26.23 \pm 1.40 \mathrm{a}$ & $9.78 \pm 3.73 \mathrm{~b}$ & $17.50 \pm 10.17 \mathrm{~b}$ & \\
Source of variation & & & & $\mathrm{P}<0.05$ \\
Treatment (A) & $\mathrm{P}<0.05$ & $\mathrm{P}<0.05$ & $\mathrm{P}<0.05$ & $\mathrm{~ns}$ \\
Cultivar (B) & $\mathrm{ns}$ & $\mathrm{P}<0.05$ & $\mathrm{P}<0.05$ & $\mathrm{~ns}$ \\
AXB (Interaction) & $\mathrm{P}<0.05$ & $\mathrm{P}<0.05$ & $\mathrm{P}<0.05$ & $\mathrm{n}$ \\
\hline
\end{tabular}

Note: Means followed by the same letter in the column did not significantly differ (Tukey test, $\mathrm{p}>0.05$ ). ns: not significant at 0.05 level.

Table 5. The effect of salt treatment and cultivar on plants' ion contents in roots (mean $\pm \mathrm{SE}$ )

\begin{tabular}{ccccc}
\hline $\begin{array}{c}\text { Salt Treatment } \\
(\mathrm{mM} \mathrm{NaCl})\end{array}$ & $\begin{array}{c}\mathrm{K}^{+} \text {Content } \\
\left(\mathrm{mg} \mathrm{g}^{-1}\right)\end{array}$ & $\begin{array}{c}\mathrm{Na}^{+} \mathrm{Content} \\
(\mathrm{mg} / \mathrm{g})\end{array}$ & $\begin{array}{c}\mathrm{K}^{+} / \mathrm{Na}^{+} \\
\text {Ratio }\end{array}$ & $\begin{array}{c}\mathrm{Cl}^{-} \text {Content } \\
(\mathrm{mg} / \mathrm{g})\end{array}$ \\
\hline Control & $14.09 \pm 1.13 \mathrm{a}^{*}$ & $0.41 \pm 0.10 \mathrm{a}$ & $37.45 \pm 3.32 \mathrm{a}$ & $2.57 \pm 0.65 \mathrm{c}$ \\
$50-100-150$ & $19.08 \pm 0.94 \mathrm{~b}$ & $6.69 \pm 0.29 \mathrm{~b}$ & $2.99 \pm 0.34 \mathrm{~b}$ & $14.09 \pm 1.98 \mathrm{~b}$ \\
150 & $18.05 \pm 1.04 \mathrm{~b}$ & $10.50 \pm 1.53 \mathrm{c}$ & $1.81 \pm 0.24 \mathrm{c}$ & $22.64 \pm 2.02 \mathrm{a}$ \\
Cultivar & $16.86 \pm 1.12 \mathrm{a}$ & $5.34 \pm 1.26 \mathrm{a}$ & $15.55 \pm 7.89 \mathrm{a}$ & $12.93 \pm 3.83 \mathrm{a}$ \\
'Hersi' & $18.06 \pm 1.30 \mathrm{a}$ & $6.40 \pm 1.82 \mathrm{a}$ & $12.62 \pm 6.58 \mathrm{a}$ & $13.27 \pm 2.23 \mathrm{a}$ \\
'ST 318' & $\mathrm{P}<0.05$ & $\mathrm{P}<0.05$ & $\mathrm{P}<0.05$ & $\mathrm{P}<0.05$ \\
Source of variation & $\mathrm{ns}$ & $\mathrm{ns}$ & $\mathrm{ns}$ & $\mathrm{ns}$ \\
\hline Treatment (A) & $\mathrm{ns}$ & $\mathrm{ns}$ & $\mathrm{ns}$ & $\mathrm{ns}$ \\
\hline Cultivar (B) & & & \\
AXB (Interaction) & & &
\end{tabular}

Note: Means followed by the same letter in the column did not significantly differ (Tukey test, $\mathrm{p}>0.05$ ). ns: not significant at 0.05 level.

Table 6. The ratio of the biochemical activity of plants under salt treatments in relation to plants under control (mean \pm SE)

\begin{tabular}{cccc}
\hline Salt Treatment & Proline & Hydrogen peroxide & Malondialdehyde \\
\hline$(\mathrm{mM} \mathrm{NaCl})$ & $\left(\mathrm{mg} \mathrm{l}^{-100 \mathrm{~g}^{-1}}\right)$ & $\left(\mu \mathrm{mol} 25 \mathrm{~g}^{-1}\right)$ & $\left(\mu \mathrm{mol} \mathrm{g}^{-1}\right)$ \\
50 & $1.9 \pm 0.01 \mathrm{c}^{*}$ & $1.2 \pm 0.04 \mathrm{a}$ & $1.0 \pm 0.06 \mathrm{a}$ \\
$50-100-150$ & $3.5 \pm 0.11 \mathrm{~b}$ & $1.1 \pm 0.02 \mathrm{~b}$ & $0.8 \pm 0.05 \mathrm{~b}$ \\
150 & $8.0 \pm 0.24 \mathrm{a}$ & $0.6 \pm 0.01 \mathrm{c}$ & $0.4 \pm 0.03 \mathrm{c}$ \\
Cultivar & & & $0.7 \pm 0.04 \mathrm{~b}$ \\
'Hersi' & $4.3 \pm 0.59 \mathrm{~b}$ & $0.95 \pm 0.08$ & $0.8 \pm 0.10 \mathrm{a}$ \\
'ST318' & $4.7 \pm 0.79 \mathrm{a}$ & $0.94 \pm 0.06$ & $\mathrm{P}<0.05$ \\
Source of variation & & & $\mathrm{P}<0.05$ \\
Treatment (A) & $\mathrm{P}<0.05$ & $\mathrm{P}<0.05$ & $\mathrm{P}<0.05$ \\
Cultivar (B) & $\mathrm{P}<0.05$ & $\mathrm{~ns}$ & $\mathrm{P}<0.05$ \\
\hline AXB (Interaction) & $\mathrm{P}<0.05$ & &
\end{tabular}

Note: Means followed by the same letter in the column did not significantly differ (Tukey test, $\mathrm{p}>0.05$ ). ns: not significant at 0.05 level. 


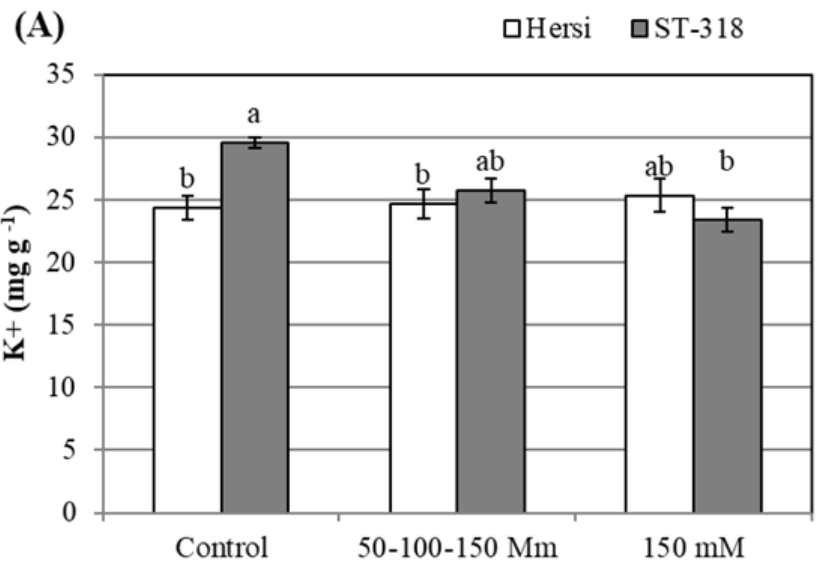

(C)

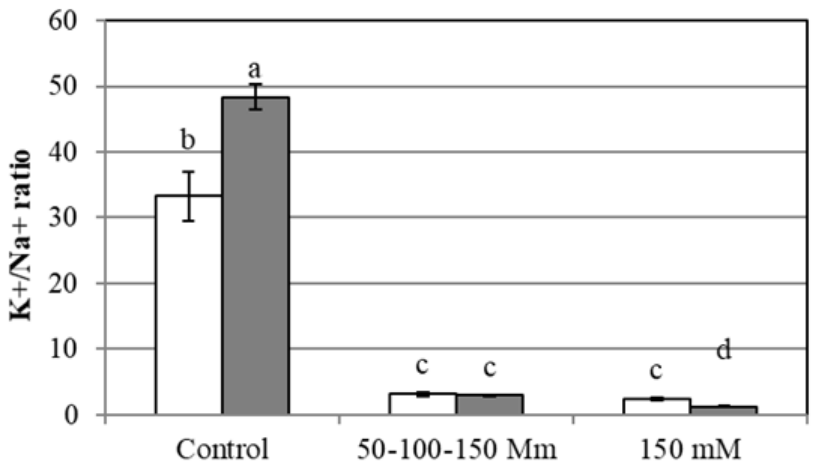

(E)

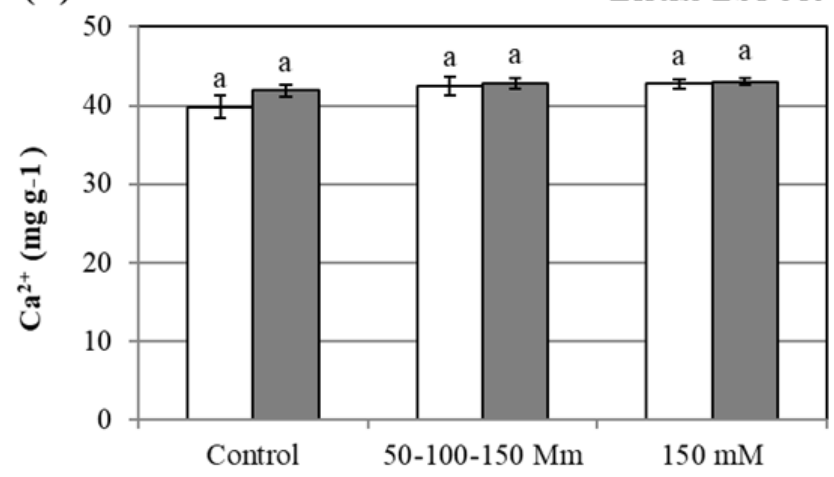

Salinity treatments
(B)

口Hersi $\square$ ST-318

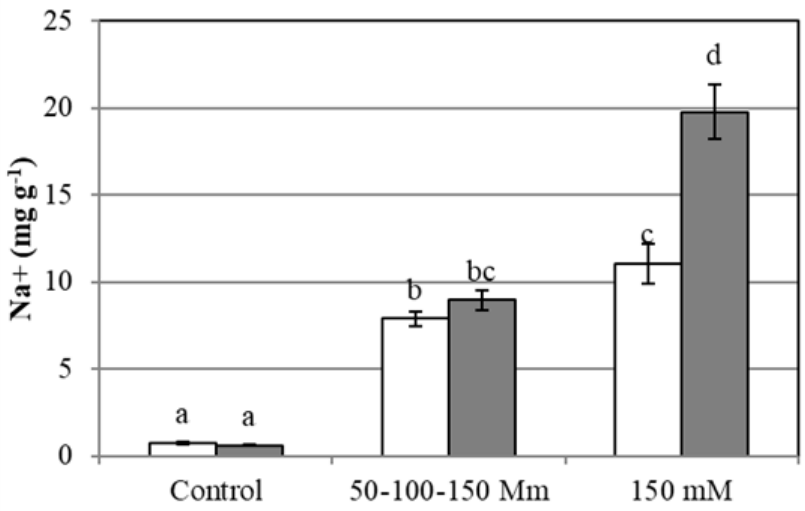

(D)

口Hersi aST-318

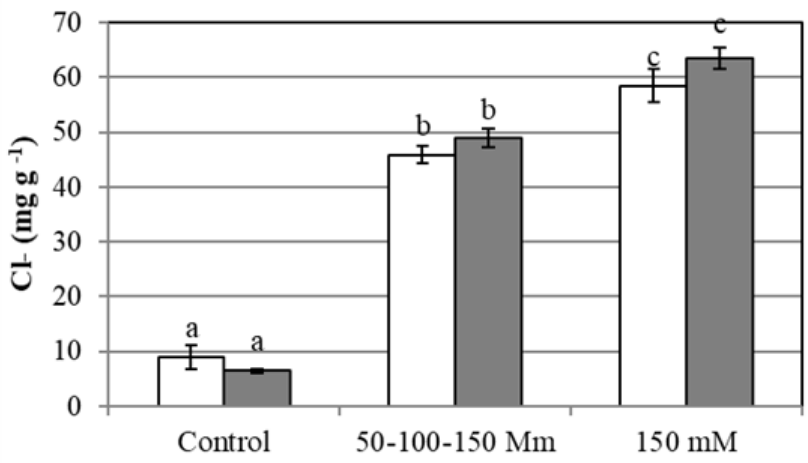

(F)

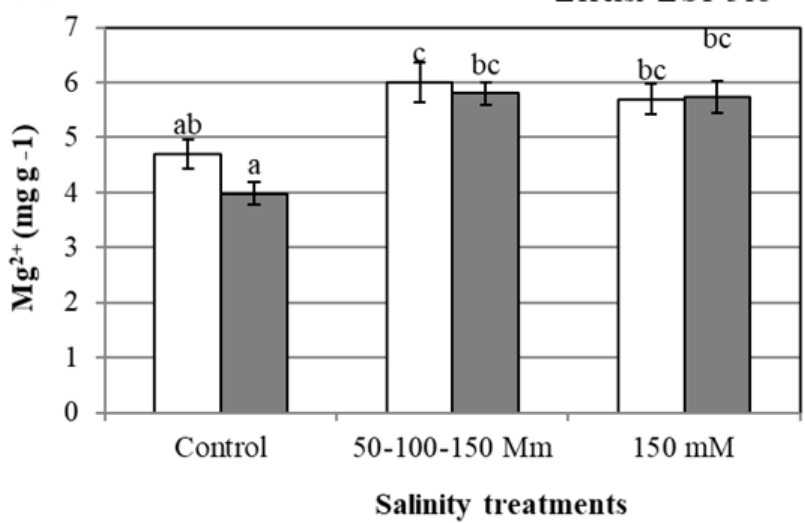

Fig. 1. The content of (A) $\mathrm{Na}^{+},(\mathrm{B}) \mathrm{K}^{+},(\mathrm{C})$ the ratio of $\mathrm{K}^{+} / \mathrm{Na}^{+}$, (D) the content of $\mathrm{Cl}^{-}$, (E) the content of $\mathrm{Ca}^{2+}$ and (F) the content of $\mathrm{Mg}^{2+}$ for cultivars 'Hersi' and 'ST- 318 ' under salinity treatments in shoots. The vertical bars indicate the mean's SE. The different letters refer to the significant differences at $\mathrm{p}<0.05$ (Tukey test) 
712
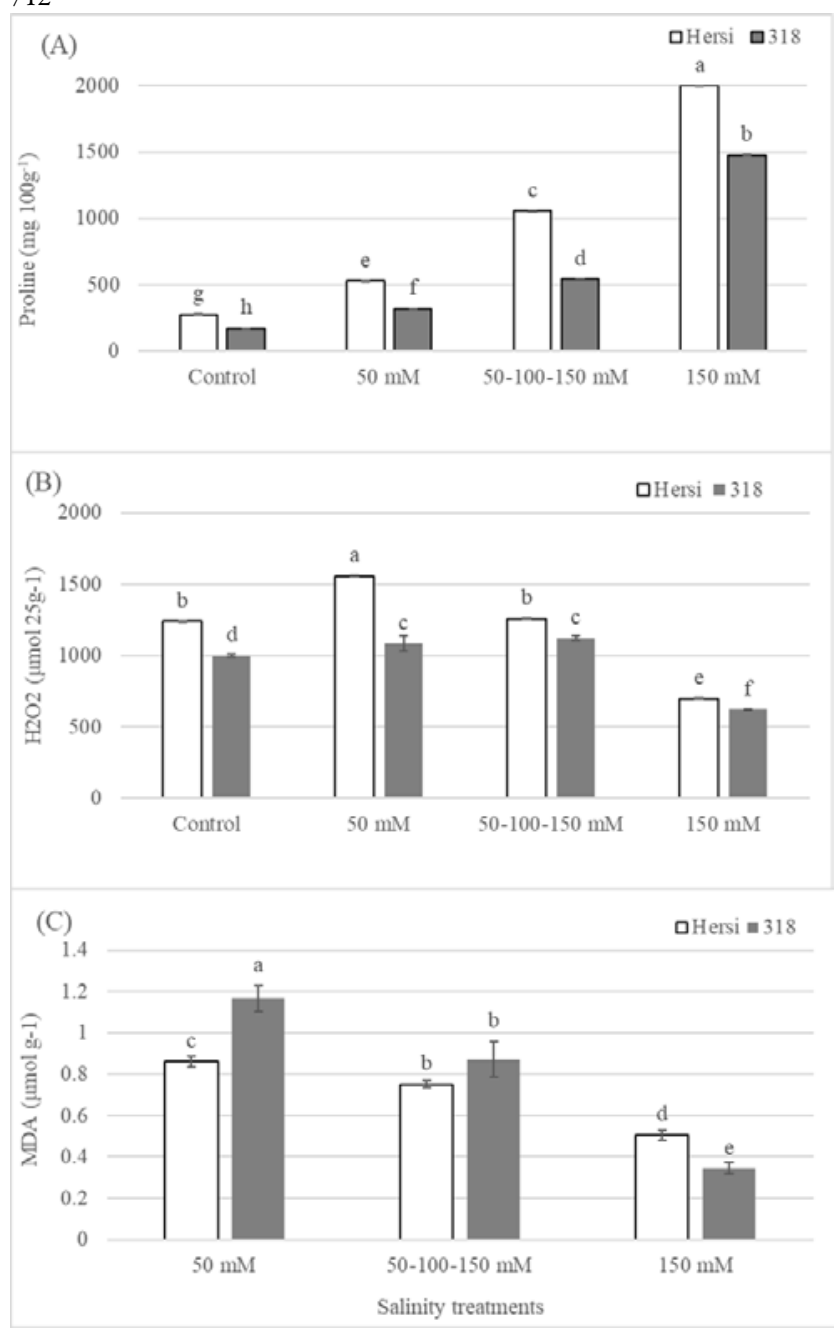

Fig. 2. The ratio in relation to control of (A) Proline (mg 100 $\left.\mathrm{g}^{-1}\right)$ content, (B) Hydrogen peroxide $\left(\mu \mathrm{mol} 25 \mathrm{~g}^{-1}\right)$ content and (C) Malondialdehyde $\left(\mu \mathrm{mol} \mathrm{g} \mathrm{g}^{-1}\right)$ content for 'Hersi' and 'ST 318 ' cultivars under salinity treatments. The vertical bars indicate the mean's SE. The different letters refer to the significant differences at $\mathrm{p}<0.05$ (Tukey test)

\section{Discussion}

Most crop plants that provide food for the world population are glycophytes and are very sensitive to high concentrations of salts in the soil, mainly $\mathrm{NaCl}$. Thus, salinity is one of the major abiotic stresses harmfully affecting crop growth and development and consequently yield and quality (Bojórquez-Quintal et al., 2014). Although cotton is considered as a relatively salt-tolerant crop, a longterm exposure may cause adverse effects on crop growth and development (Higbie et al., 2010). To this end three salinity treatments were applied: a low dose $(50 \mathrm{mM}$ of $\mathrm{naCl})$ a gradual (step-wise) acclimatization and an initial acclimatization to a non-lethal $\mathrm{NaCl}$ concentration (150 $\mathrm{mM}$ ) in two commercial Greek cultivars in order to determine the degree of the tolerance of these cultivars to salt stress and unravel their responses with respect to different salt treatments. The two cultivars did not differ significantly regarding their tolerance to low levels of salt stress $(50 \mathrm{mM})$. On the contrary they showed differences when subjected to both initial and gradual acclimatization of $150 \mathrm{mM}$ of $\mathrm{NaCl}$ as indicated by several growth, gas exchange and biochemical parameters.

\section{Growth and physiological parameters}

The inhibition of normal growth of the plant is the immediate visual result of salinity stress. As it was found, all salinity treatments resulted in impairment of plant biomass for the two cotton cultivars. The inhibition of the growth consists of the significant reduction of the net and dry weights of leaves, shoots and roots as it is demonstrated in several studies (Basal, 2010; Rahnama et al., 2010; Zhang et al., 2014). The reduction of plant height was similar in both cultivars and higher under the initial acclimatization of 150 $\mathrm{mM} \mathrm{NaCl}$ compared to the gradual acclimatization. On the other hand, Hersi showed lower reduction rates in growth parameters such as shoot, root and stem dry weight indicating better tolerance ability. Similar conclusions were reported by (Zhang et al., 2014) when they estimated the salinity tolerance of two cotton cultivars by comparing their morphological responses. This reduction in growth parameters was again more profound when plants were subjected to initial salt stress instead of gradual acclimatization and may be due to a reduction in water potential and accumulation of toxic ions ( $\mathrm{Zhu}, 2001$; Munns, 2002). In addition, the highest salinity sensitivity index (Campanelli et al., 2013), regarding root dry weight was recorded for 'ST 318' indicating that 'Hersi' responded better than 'ST318' under salt stress in terms of growth parameters.

Application of $\mathrm{NaCl}$ caused a decrease in $\mathrm{A}, \mathrm{E}$, gs and $\mathrm{Ci}$ concentration. Interestingly, no profound differences were monitored in photosynthetic parameters between the initial and the gradual acclimatization. However, 'Hersi' was the one that demonstrated higher gas exchange parameters (i.e A, gs, Ci, E) compared to 'ST 318'. On the other hand the reduction of A in 'ST 318' as well as the reduction in $\mathrm{Ci}$ is mainly due to the closure of the stomata, as indicated in other reports as well (Brugnoli and Lauteri, 1991; Zhang et al., 2014). In spite of the higher stomatal conductance of 'Hersi', the two varieties did not differ significantly in terms of the utilization of available water. Interestingly, initial and gradual acclimatization on $\mathrm{NaCl}$ had no effect on WUE, and plants from both cultivars managed to maintain their WUE at similar levels compared to the controls.

Since 'Hersi' showed higher gs, but both cultivars displayed almost the same water use efficiency, it could be suggested that 'Hersi' was capable of maintaining the same E with increased gs and increased A so overall it demonstrated better adaptability to salt stress. The ability to maintain open stomata and to perform fully functional photosynthesis even under stressful conditions has been documented as an indication of tolerance in several other studies (Holá et al., 2017; Zhu et al., 2018). In this regard, the superiority of 'Hersi' in biomass production under salt stress probably could be attributed to this ability.

\section{Ion homeostasis}

In this study, although salinity treatment disrupted the $\mathrm{K}^{+} / \mathrm{Na}^{+}$balance only $\mathrm{Na}^{+}$content was significantly increased in response to salt treatments. More specifically, 
under salinity treatments and especially under initial acclimatization of $150 \mathrm{mM} \mathrm{NaCl}$, the $\mathrm{Na}^{+}$contents of leaves and roots in both cultivars were profoundly increased. However, 'Hersi' seemed to control $\mathrm{Na}^{+}$accumulation in both leaves and roots better than 'ST 318'. In several studies, plant adaptation to salt stress is attributed to the ability of maintaining a low $\mathrm{Na}^{+}$content and better regulating $\mathrm{Na}^{+}$ ion homeostasis (Munns and Tester, 2008; Dai et al., 2014; Kong et al., 2016; Wang et al., 2016).

Salinity decreased $\mathrm{K}^{+}$concentrations in leaves, but increased its concentration in roots, suggesting that salt stress prohibited $\mathrm{K}^{+}$transport from roots to leaves. Similar results were shown by Wang et al. (2017a). On the other hand, $\mathrm{K}^{+}$content maintained at the same level in leaves of the two cultivars (Table 4). Tolerant genotypes are also capable of preserving $\mathrm{K}^{+}$homeostasis during all salt stress stages (Hauser and Horie, 2010; Shabala, 2013; Almeida et al., 2017). Therefore, $\mathrm{K}^{+}$is considered as a key regulatory element in plant metabolic process by promoting $\mathrm{Na}^{+}$ exclusion and regulating osmotic adjustment (Chakraborty et al., 2016).

Having a stable $\mathrm{K}^{+} / \mathrm{Na}^{+}$ratio in tissues is critical for plant growth and metabolism under saline conditions (Wang et al., 2016). According to the results of the present study, $\mathrm{K}^{+} / \mathrm{Na}^{+}$ratio was profoundly higher in leaves of 'Hersi' cultivar's plants subjected to initial acclimatization compared to 'ST 318's plants. However, this ratio was not differentiated between the two cultivars under gradual acclimatization. These results are in accordance to recent findings by (Wang et al., 2017a) were they demonstrated that the $\mathrm{K}^{+} / \mathrm{Na}^{+}$ratio of the salt sensitive cultivar ' $\mathrm{Z} 571$ ' decreased 14 times whereas in tolerant cultivars ('CCRI44', 'CZ91') the $\mathrm{K}^{+} / \mathrm{Na}^{+}$ratio was reduced 4-8 times between control and salt treated plants.

In addition, there was a profound increase in $\mathrm{Cl}^{-}$content in the salt-treated plants in leaves and roots of both cultivars. The fact that high $\mathrm{Cl}^{-}$content doesn't seem to influence the salt tolerance of the two cultivars could be a consequence of the restriction of entry of $\mathrm{Cl}^{-}$ions into metabolically active areas of cells as a mechanism to maintain ionic equilibrium when ions are highly concentrated in the external environment (Niu et al., 1995).

Calcium plays a central role in membrane stability and $\mathrm{K}^{+} / \mathrm{Na}^{+}$homeostasis (Grattan and Grieve, 1999). In addition, calcium is implicated in salt tolerance by enhancing ion uptake and ameliorating plant osmotic adjustment (Epstein, 1998). Moreover, it has been documented that salinity negatively affects $\mathrm{Mg}^{2+}$ uptake, and this decrease may influence the activity of some enzymes, which require $\mathrm{Mg}^{2+}$ for catalysis as well as chlorophyll synthesis (Khan et al., 2000). In the present study, both calcium and magnesium content remained almost unchanged in leaves of both cultivars in all salt treatments. The capacity of both cultivars in preserving the same ion uptake in control and salt stress conditions further supports the hypothesis that both cultivars are tolerant.

\section{Lipid peroxidation and proline accumulation}

Salt stress is known to result in extensive lipid peroxidation (measured by MDA content), as a consequence of accumulation of ROS. In both 'Hersi' and 'ST 318' an increase in both $\mathrm{H}_{2} \mathrm{O}_{2}$ (the most abundant
ROS) and MDA was monitored in the plants watered with $50 \mathrm{mM} \mathrm{NaCl}$ compared to the controls, however in the plants subjected to higher concentrations of $\mathrm{NaCl}$ (either initial or gradual acclimatization) decreased levels of both $\mathrm{H}_{2} \mathrm{O}_{2}$ and $\mathrm{MDA}$ were observed. Although these observations are a bit unusual, similar results were obtained by (Ozturk et al., 2012) when they subjected pea varieties to different concentrations of $\mathrm{NaCl}$ and they also measured reduced levels of $\mathrm{H}_{2} \mathrm{O}_{2}$ and $\mathrm{MDA}$ in higher concentrations of $\mathrm{NaCl}$. These results are also in agreement with studies of (Kennedy and De Filippis, 1999) in Grevillea ilicifolia and (Freitas et al., 2011) in cotton varieties.

Wang $\mathrm{Y}$ et al. (2016) measured the $\mathrm{H}_{2} \mathrm{O}_{2}$ content and MDA content on a salt tolerant cotton variety over a period of $24 \mathrm{~h}$ after imposition of $\mathrm{NaCl}$ (plants were transferred to a nutrient solution containing $200 \mathrm{mmol} / \mathrm{L} \mathrm{NaCl}$ ). They found that both $\mathrm{H}_{2} \mathrm{O}_{2}$ and MDA content increased rapidly until 6 and 12 hours respectively after $\mathrm{NaCl}$ treatment and then they both dropped. These results probably suggest that in tolerant genotypes $\mathrm{H}_{2} \mathrm{O}_{2}$ accumulation up to a certain point my act as a signaling molecule mediating responses and triggering antioxidant activity but then it drops to lower levels in order not to cause oxidative stress. The reduction of MDA and $\mathrm{H}_{2} \mathrm{O}_{2}$ compared to controls in both cultivars suggest that they both possess an effective ROS scavenging mechanism, although the measurement of antioxidant enzymes activity is required.

Finally accumulation of osmolytes, especially that of proline, is one of the most common plant responses in order to adapt to adverse environmental conditions such as drought and salt stress. Proline has a multifunctional role besides being an osmolyte, and contributes to a plethora of biochemical pathways leading to scavenging ROS, stabilizing subcellular structures, modulating cell redox homeostasis etc (Verbruggen and Hermans, 2008; Bojórquez-Quintal et al., 2014; Gharsallah et al., 2016)). Proline is accumulated mainly in leaves in order to maintain chlorophyll level and cell water content and consequently to protect photosynthetic activity under salt stress (SilvaOrtega et al., 2008).

In the present study, the extent of proline accumulation varied in the two cotton cultivars, and proline accumulation in Hersi cultivar increased greatly (up to 8 times) in initial and gradual acclimatization of $150 \mathrm{mM} \mathrm{NaCl}$ compared to the controls. In 'ST 318', there was a proline accumulation in all salt treatments compared to control but not to the same extent as in 'Hersi'.

\section{Conclusions}

As an overall conclusion, both cultivars performed quite well in saline conditions compared to other cotton cultivars. The observed salt tolerance could be correlated with two characters (defense mechanisms) that they share: a) a rapid antioxidant capacity, and b) $\mathrm{K}^{+} / \mathrm{Na}^{+}$homeostasis. The gradual acclimatization had a mild effect of all studied parameters apart from the gas exchange ones for both cultivars. However, 'Hersi' cultivar was found more tolerant to salinity as it performed better in terms of growth. This can be attributed to better gas exchange parameters, better control of $\mathrm{K}^{+} / \mathrm{Na}^{+}$ratio and more efficient membrane homeostasis. It has to be noted that a special feature of 
714

'Hersi' as indicated by the company that distributes it, is its deep rooting system. It would be very interesting to further explore the impact of it towards salt stress tolerance in cotton plants. Identification of salt tolerant cotton genotypes for salt affected areas can benefit the farming community through increased seed cotton yield and quality thus cotton cultivation could be expanded to these areas as well.

\section{Acknowledgements}

This research received no specific grant from any funding agency in the public, commercial, or not-for-profit sectors. We would like to thank GREENCO and PIONEER HELLAS for providing the seeds and Anastasios Katsileros for technical assistance.

\section{References}

Akhtar J, Saqib ZA, Sarfraz M, Saleem I, Haq MA (2010). Evaluating salt tolerant cotton genotypes at different levels of $\mathrm{NaCl}$ stress in solution and soil culture. Pakistan Journal of Botany 42(4):2857-2866.

Akhtar J, Saqib ZA, Sarfraz M, Saleem I, Haq MA (2010). Evaluating salt tolerant cotton genotypes at different levels of $\mathrm{NaCl}$ stress in solution and soil culture. Pakistan Journal of Botany 42(4):2857-2866.

Alexieva V,Sergiev I, MapelliS, KaranovE(2001). The effect of drought and ultraviolet radiation on growth and stress markers in pea and wheat. Plant, Cell \&Environment 24(12):1337-1344.

Almeida DM, Oliveira MM, Saibo NJM (2017). Regulation of Na+ and $\mathrm{K}+$ homeostasis in plants: towards improved salt stress tolerance in crop plants. Genetics and Molecular Biology 40(1):326-345.

Ashraf M (2002). Salt tolerance of cotton: Some new advances. Critical Reviews in Plant Sciences 21(1):1-30.

Ashraf M, Foolad MR (2007). Roles of gycine betaine and proline in improving plant abiotic stress resistance. Environmental and Experimental Botany 59(2):206-216.

Ashraf M, Wu L (1994). Breeding for salinity tolerance in plants. Critical Reviews in Plant Sciences 13(1):17-42.

Basal HPJB (2010). Response of cotton (Gossypium hirsutum L.) genotypes to salt stress. Pakistan Journal of Botany 42(1):505-511.

Bates LS, Waldren RP, Teare ID (1973). Rapid determination of free proline for water-stress studies. Plant Soil (39):205-207.

Bojórquez-Quintal E, Velarde-Buendía A, Ku-González Á, Carillo-Pech M, Ortega-Camacho D, Echevarría-Machado I, ... Martínez-Estévez M (2014). Mechanisms of salt tolerance in habanero pepper plants (Capsicum chinense Jacq.): Proline accumulation, ions dynamics and sodium root-shoot partition and compartmentation. Frontiers in Plant Science 5:605-619.

Brugnoli E, Lauteri M (1991). Effects of salinity on stomatal conductance, photosynthetic capacity, and carbon isotope discrimination of salttolerant (Gossypium hirsutum L.) and salt-sensitive (Phaseolus vulgaris L.) C(3) non-halophytes. Plant Physiology 95(2):628-635.

Campanelli A, Ruta C, Morone-Fortunato I, De Mastro G (2013). Alfalfa (Medicago sativa $\mathrm{L}$.) clones tolerant to salt stress: in vitro selection. Central European Journal of Biology 8(8):765-776.
Carillo P, Annunziata MG, Pontecorvo G, Fuggi A, Woodrow P (2011) Salinity stress and salt tolerance. In: Shanker AK, Venkateswarlu B(Eds). Abiotic Stress in Plants - Mechanisms and Adaptations B.). IntechOpen pp 21-38.

Chakraborty K, Bose J, Shabala L, Shabala S (2016). Difference in root K+ retention ability and reduced sensitivity of $\mathrm{K}+$-permeable channels to reactive oxygen species confer differential salt tolerance in three Brassica species. Journal of Experimental Botany 67(15):4611-4625.

Constable GJCK, llewelyn D, Walford S (2015). Cotton breeding for fiber quality improvement. In: Cruz VMV, Dierig DA (Eds). Industrial Crops. Handbook of Plant Breeding, vol 9. Springer, New York, NY pp 191-232.

Dai JL, Duan LS, Dong HZ (2014). Improved nutrient uptake enhances cotton growth and salinity tolerance in saline media. Journal of Plant Nutrition 37(8):1269-1286.

Dogan I, Ozyigit I, Demir G (2012). Mineral element distribution of cotton (Gossypium hirsutum L.) seedlings under different salinity levels. Pakistan Journal of Botany 44(SI):15-20.

Epstein E (1998). How calcium enhances plant salt tolerance. Science 280 (5371):1906-1907.

Freitas VS, Alencar NLM, de Lacerda CF, Prisco JT, Eneas G-F (2011). Changes in physiological and biochemical indicators associated with salt tolerance in cotton, sorghum and cowpea. African Journal of Biochemistry Research 5(8):264-271.

Gharsallah C, Fakhfakh H, Grubb D, Gorsane F (2016). Effect of salt stress on ion concentration, proline content, antioxidant enzyme activities and gene expression in tomato cultivars. AoB Plants 8:plw055.

Grattan SR, Grieve CM (1999). Salinity-mineral nutrient relations in horticultural crops. Scientia Horticulturae 78(1-4):127-157.

Hadi MR, Karimi N (2012). The role of calcium in plants' salt tolerance. Journal of Plant Nutrition 35(13):2037-2054.

Hamrouni L, Ben Abdallah F, Abdelly C, Ghorbel A (2008). La culture in vitro: un moyen rapide et efficace pour sélectionner des génotypes de vigne tolérant la salinité. [ In vitro culture:a simple and efficient way for salt-tolerant grapevine genotype selection]. Comptes Redus Biologies 331(2):152-163.

Hasegawa PM, Bressan RA, Zhu J-K, Bohnert HJ (2000). Plant cellular and molecular responces to high salinity. Annual Review of Plant Physiology and Plant Molecular Biology 51(1):463-499.

Hauser F, Horie T (2010). A conserved primary salt tolerance mechanism mediated by HKT transporters: a mechanism for sodium exclusion and maintenance of high $\mathrm{K}+/ \mathrm{Na}+$ ratio in leaves during salinity stress. Plant, Cell \&Environment 33(4):552-565.

Heath RL, Packer L (1968). Photoperoxidation in isolated chloroplasts: I Kinetics and stoichiometry of fatty acid peroxidation. Archives of Biochemistry and Biophysics 125(1):189-198.

Higbie SM, Wang F, Stewart JM, Sterling TM, Lindemann WC, Hughs E Zhang J (2010). Physiological response to salt $(\mathrm{NaCl})$ stress in selected cultivated tetraploid cottons. International Journal of Agronomy 643475.

Holá $D$, Benešová $M$, Fischer $L$, Haisel $D$, Hnilička $F$, Hniličková $H, \ldots$ Wilhelmová $N$ (2017). The disadvantages of being a hybrid during 
drought: A combined analysis of plant morphology, physiology and leat proteome in maize. PLoSOne 12(4):e0176121.

Jones JrJB (2001). Laboratory guide for conducting soil tests and plant analysis. CRC Press $384 \mathrm{p}$.

Kennedy BF, De Filippis LF (1999). Physiological and oxidative response to nacl of the salt tolerant Grevillea ilicifolia and the salt sensitive Grevillea arenaria. Journal of Plant Physiology 155(6):746-754.

Khan MA, Ungar IA, Showalter AM (2000). The effect of salinity on the growth, water status, and ion content of a leaf succulent perennial halophyte, Suaeda fruticosa (L.) Forssk. Journal of Arid Environments 45(1):73-84.

Kong X, Luo Z, Dong H, Eneji AE, Li W (2016). $\mathrm{H}_{2} \mathrm{O}_{2}$ and ABA signaling are responsible for the increased $\mathrm{Na}+$ efflux and water uptake in Gossypium hirsutum L. roots in the non-saline side under non-uniform root zone salinity.Journal of Experimental Botany 67 (8):2247-2261.

Leidi EO, Saiz JF (1997). Is salinity tolerance related to $\mathrm{Na}$ accumulation in upland cotton (Gossypium hirsutum) seedlings? Plant and Soil 190(1):67-75.

Munns R(2002). Comparative physiology of salt and water stress. Plant, Cell andEnvironment 25(2):239-250.

Munns R, Gilliham M (2015). Salinity tolerance of crops - what is the cost? New Phytologist 208(3):668-673.

Munns R, Tester M (2008). Mechanisms of salinity tolerance. Annual Review of Plant Biology 59:651-681.

Niu X, Bressan RA, Hasegawa PM, Pardo JM (1995). Ion homeostasis in $\mathrm{NaCl}$ stress environments. Plant Physiology 109(3):735-742.

Ozturk L, Demir Y, Ünlükara A, Karatas I, Kurunc A, Duzdemir O (2012). Effects of long-term salt stress on antioxidant system, chlorophyll and proline contents in pea leaves. Romanian Biotechnological Letters 17(3):7227-7236.

Ozyigit II, Dogan I, Demir G, Yalcin IE (2017). Mineral nutrient acquisition by cotton cultivars grown under salt stress. Communications in Soil Science and Plant Analysis 48 (8):846-856.

Parida AK, Das AB (2005). Salt tolerance and salinity effects on plants: a review. Ecotoxicology and Environmental Safety 60(3):324349.

Parihar P, Singh S, Singh R, Singh VP, Prasad SM (2015). Effect of salinity stress on plants and its tolerance strategies: a review. Environmental Science and Pollution Research 22(6):4056-4075.

Peng Z, He S, Sun J, Pan Z, Gong W, Lu Y, Du X (2016). Na+ compartmentalization related to salinity stress tolerance in upland cotton (Gossypium hirsutum) seedlings. Scientific Reports 6:34548.

Rahnama A, Poustini K, Tavakkol Afshari R, Tavakoli A (2010). Growth and stomatal responses of bread wheat genotypes in tolerance to salt stress. International Journal of Agricultural and Biosystems Engineering 6(10):787-792.
Rahneshan Z, Nasibi F, Moghadam AA (2018). Effects of salinity stress on some growth, physiological, biochemical parameters and nutrients in two pistachio (Pistacia vera L.) rootstocks. Journal of Plant Interactions 13(1):73-82.

Razzouk S, Whittington WJ (1991). Effects of salinity on cotton yield and quality. Field Crops Research 26(3):305-314.

Shabala S (2013). Learning from halophytes: physiological basis and strategies to improve abiotic stress tolerance in crops. Annals of Botany 112(7):1209-1221.

Silva-Ortega CO, Ochoa-Alfaro AE, Reyes-Agüero JA, Aguado-Santacruz GA, Jiménez-Bremont JF (2008). Salt stress increases the expression of $\mathrm{p} 5 \mathrm{cs}$ gene and induces proline accumulation in cactus pear. Plant Physiology and Biochemistry 46(1):82-92.

Thu TTP, Yasui H, Yamakawa T (2017). Effects of salt stress on plant growth characteristics and mineral content in diverse rice genotypes. Soil Science and Plant Nutrition 63(3):264-273.

Verbruggen N,Hermans C (2008). Proline accumulation in plants: a review. Amino Acids 35(4):753-759.

Wang N, Qi H, Qiao W, Shi J, Xu Q, Zhou H, Yan G, Huang Q(2017a). Cotton (Gossypium hirsutum $\mathrm{L}$.) genotypes with contrasting $\mathrm{K}+/ \mathrm{Na}+$ ion homeostasis: implications for salinity tolerance. Acta Physiologia Plantarum 39(3):77-87.

Wang N, Qi H, Su G, Yang J, Zhou H, Xu Q, Huang Q, Yan G (2016). Genotypic variations in ion homeostasis, photochemical efficiency and antioxidant capacity adjustment to salinity in cotton (Gossypium birsutum L.). Soil Science and Plant Nutrition 62(3):240-246.

Wang N, Qiao W, Liu X, Shi J, Xu Q, Zhou H, Yan G, Huang Q(2017b). Relative contribution of $\mathrm{Na}+\mathrm{K}+$ homeostasis, photochemical efficiency and antioxidant defense system to differential salt tolerance in cotton (Gossypium hirsutum L.) cultivars. Plant Physiology and Biochemistry 119:121-131.

Wang Y,LiX,LiJ, Bao Q,ZhangF, Tulaxi G, WangZ(2016).Salt-induced hydrogen peroxide is involved in modulation of antioxidant enzymes in cotton. The CropJournal 4(6):490-498.

Zhang L, Ma H, Chen T, Pen J, Yu S, Zhao X (2014). Morphological and physiological responses of cotton (Gossypium hirsutum L.) plants to salinity. PLoSOne 9(11):e112807.

Zhu J-K (2001). Cell signaling under salt, water and cold stresses. Current Opinion in Plant Biology 4(5):401-406.

Zhu X, Cao Q, Sun L, Yang X, Yang W, Zhang H (2018). Stomatal conductance and morphology of arbuscular mycorrhizal wheat plants response to elevated $\mathrm{CO}_{2}$ and $\mathrm{NaCl}$ stress. Frontiers in Plant Science $9: 1363$. 